dan kritikus ataupun ahli harus aktif melibatkan diri dalam penilaian kembali ini. Karya ini akan memungkinkan terciptanya studi baru dan pandangan baru tentang pengarang Indonesia dan karyanya, sebagai dukungan pada proses pembenahan kanon sastra Indonesia yang sangat penting dan terus berlangsung.

J. J. Rizal
Peneliti sejarah dan sastra di Komunitas Bambu,
Jakarta

\title{
Membaca Sketsa Estetika Kehidupan
}

Mudji Sutrisno, Oase Estetis, Estetika dalam Kata dan Sketza (Yogyakarta: Penerbit Kanisius, 2006), vi + 245 halaman.

Pada awalnya adalah kata

Pada awalnya adalah garis

Bagi yang biasa berkata-kata

Belajarlah dalam dialog-dialog

Hati proses berestetika dengan garis, warna, simbol

Belajarlah karakter garis saudara-saudarimu, dan seterusnya (hlm. 1)

Puisi Credo menjadi "pembuka” bagi perjalanan seorang Mudji Sutrisno dalam mengarungi kehidupan ini. Berbagai gaya pemikirannya dituangkannya ketika menjalani dan berdialog pada kepekaan kehidupan, bahkan menggores garis sehingga sketsa-sketsa itu hadir. Buku Oase Estetis ini memuat tema yang cukup padat, yaitu budaya, estetika, kritik estetika, humanisme, ruang, sastra, dan filsafat, Yunani, dan dari kawan. Dalam tulisan tentang budaya, Air menjadi pertanyaan kritis. Air tidak lagi sekadar sumber kehidupan, sumber sakral dalam religi tirta masyarakat Bali (hlm.5), tetapi menjadi kesewenangan pemakaiannya ketika para turis di hotel ataupun pelaku budaya ekonomisasi dan konsumerisasi tak bertanggung jawab atas pemakaian air yang sangat berlebihan. Sumber mata air lambat laun menjadi kering ketika para kapitalis berlomba untuk mengemasnya menjadi sebagian minuman bagi masyarakat dan tragisnya penduduk di sekitar mata air kekurangan air. Bagi Mudji Sutrisno keprihatinan tentang air dituangkannya melalui peristiwa seni Apuan (hlm. 6) dan berbagai puisi (cuplikan) yang berasal Putu Raka dan 
Tjokorda (hlm. 7).

Air membuat kita tergugah untuk sadar terhadap akan budaya sadar diri dan itulah yang membuat kita menjadi sadar diri terhadap estetika dan estetika tubuh. Eksotika badani dan pandangan yang melulu terarah terhadap hasrat tubuh (hlm. 42) menjadi sorotan kapitalisme konsumerisme. Hal itu telah hadir pada masa Victorian hingga kini, terekspresi melalui ruang penikmatan dan ragam budaya tubuh eksotis. Tubuh yang seharusnya menjadi sesuatu yang sakral mengalami transisi bahkan dekonstruksi ketika kesadaran kita terfokus pada pemujaan terhadap tubuh dan menjadi arena konsumsi dan objek penikmatan bagi pelaku budaya. Secara lugas ini menjadi sesuatu yang berani ketika Mudji Sutrisno melihat bahwa ada dikotomi yang tercermin pada estetika tubuh (hlm. 43) mengenai nakedness (baca: kebugilan) yang menonjolkan erotika, ditampilkan vulgar dan nudity (baca: kepolosan telanjang) dianggap sebagai pengendapan seorang seniman yang mencapai titik estetika atau sublimasi antara yang indah dan yang baik. Contoh yang ditampilkan adalah penggambaran estetika tubuh polos pada relief candi Prambanan dan Borobudur, dan kita tidak perlu berdebat mengenai hal itu dan telah bersepakat mengenai itu sebagai karya seni. Pemahaman tentang apresiasi estetika tubuh mengenai seni polos hendaknya dipahami sebagai dan sesuai dengan konteks yang holistik, tidak terpotong menjadi bagian-bagian yang akan mengundang salah tafsir. Sebagai ekspresi estetika tubuh karya seni dapat memunculkan simbol, sindiran, metafora, seni instalasi dengan teknologi digital mutakhir, bahkan wajah idola masyarakat yang semuanya harus diapresiasi sebagai penafsiran tanda semiotik. Dengan demikian, kita menjadi lebih arif dan objektif menilai substansi estetika tubuh pada sebuah karya seni ketika berada di ruang pubik.

Kesadaran tentang sadar budaya membawa manusia pada suatu sikap yaitu mencapai titik estetika (hlm. 74), yaitu suatu momentum pengalaman kesadaran diri manusia (seniman maupun pengapresiasi seni) yang berada di tengah antara dua kutub, aspek rohaniah dan aspek jasmaniah. Titik itu kemudian hanya dipahami sekejap, namun mendalam, memunculkan berbagai situasi rohaniah seperti sublimasi, asri, tragis, kelucuan, keriangan, keindahan. Kesadaran itu pula yang membuat Mudji Sutrisno harus memberikan penjelasan teoretis mengenai estetika dan pengalaman estetis dengan panjang lebar disertai tokohnya (hlm. 51). Agaknya pemahaman dan apresiasi seseorang mengenai estetika haruslah disertai pembekalan awal mengenai teori estetika (teori mengenai keindahan dan teori seni).

Berbicara mengenai estetika tidak akan lengkap apabila tidak menyentuh manusianya. Manusia menjadi pelaku atau aktor budaya, ia memiliki kesadaran, kebebasan, tanggung jawab, hak-hak yang diperolehnya baik sebagai seorang anggota masyarakat maupun sebagai pekerja seni atau profesi lainnya. Melalui pengalaman kebahasaannya, manusia mengekpresikan perasaannya melalui puisi, perenungan tentang dirinya atau orang lain dan situasi lainnya. Itulah yang ingin ditampilkan dalam buku Oase Estetis mengenai nilai humanisme melalui berbagai puisi seperti Puisi Berbisik 
(hlm.101) yang menggambarkan seorang "AKU" berdialog dengan sang Pencipta, jagad raya dan kecil.

Perjalanan seseorang (AKU) mengenai estetika agaknya harus menyentuh estetika ruang (hlm. 125). Ruang tidak hanya dipahami sebagai ruang ontologis, tetapi ruang metafisis. Ruang ontologis memiliki media yang dapat tersentuh oleh pancaindera manusia. Kanvas adalah ruang ontologis bagi seorang pelukis karena ia mampu menggoreskan sesuatu (lukisan) di atasnya, tetapi sekaligus juga ia mengisi kanvas dengan ruang metafisis. Mudji menyebutnya sebagai ruang batin kita, ruang dalam (hlm. 136--145). Apabila ruang batin kita dipenuhi dengan nurani pribadi, maka ruang publik adalah ruang yang dibuat dari mufakat, konsensus, kontrak sosial di antara pribadi penyusun masyarakat, yang disepakati untuk diatur bersama dalam kepastian keamanan, kesejahteraan, dan kedamaian dengan sistem hukum sehingga tidak menimbulkan konflik di antara para warganya.

Salah satu hal yang dianggap menyesakkan Mudji Sutrisno adalah ketika ruang publik yang dicontohkan sebagai ruang publik bernama Jalan Percetakan Negara (hlm. 151) tidak lagi menjadi kenyataan yang menghargai sebagai milik bersama yang saling menghormati kepentingan bersama. Jalan menjadi macet, penuh dengan mobil yang diparkir dan diatur oleh juru parkir dan warga (yang telah membayar sejumlah pajak) sehingga kehilangan hak pelayanan balik dalam hal memakai jalan publiknya.

Bagi "AKU" (dibaca seseorang) perjalanannya mempelajari sastra dan filsafat menjadi lengkap lagi apabila memiliki sejumlah pengalaman kehidupan (hlm.157). Filsafat merupakan refleksi atas pengalaman kehidupannya dan itu diekspresikannya melalui bahasa, tidak hanya bahasa filsafat yang berciri teknis, logis tetapi juga bahasa sastra yang berciri puitis dan imajinatif. Filsafat dan sastra dapat bekerja sama melalui titik temu, yaitu pengalaman hidup empiris, dan pernyataan atau argumen. Apabila filsafat dianggap sulit, sangat abstrak, sastra dapat mencairkannya melalui bahasa sastra yang komunikatif, segar, dan hidup (hlm. 159). Refleksi atas hidup secara susastra ini dapat memberikan angin segar ketika pengalaman duniawi harus dimaknai dengan bahasa logika. Perjalanan sastra dan masyarakat politis menjadi sasaran Mudji Sutrisno untuk mencermati puisi-puisi Taufik Ismail yang mengiringi pergolakan politis pada tahun 1965--1966, atau Umar Kayam (Bawuk, 1975) dan menggugat nilai-nilai pokok kemanusiaan. Menggugat nilai kemanusiaan inilah yang diprihatinkan karena memunculkan penilaian hitam ataukah putih, bersih ataukah kotor lingkungan bagi sekelompok masyarakat.

Refleksi atas kehidupan membuat Mudji Sutrisno membandingkan Socrates dan Hatta dalam hal pencerdasan kehidupan. Pemikiran Bung Hatta dalam buku Alam Pikiran Yunani (1980), terutama mengenai hidup macam apa yang harus dipahami dan dimaknai khususnya bagi bangsa Indonesia yang terjajah dan berjuang untuk merdeka, membuat Mudji Sutrisno mengaitkannya dengan pernyataan Socrates "hidup yang tidak direnungi dalam refleksi bukanlah hidup yang manusiawi (Apologia, Bab 38a). Hidup yang didialogkan baik antara guru dan murid secara sejajar akan menjadi 
agora (ruang publik) untuk saling bertemu di pasar, kebutuhan cakap bicara, kebutuhan religi hingga ke cita-cita memperbaiki diri dalam hidup bersama (politik) sebagai warga negara dan membangun negara kultural.

Dialog dan tragedi kehidupan diawali ketika bersentuhan dengan kebudayan yang harus dipahami apabila kita memiliki kesadaran diri secara total sehingga kerancuan dan penyeragaman budaya dapat dihindari. Ketika pemahaman akan ekspresi estetis hingga kritik estetika kebudayaan, maka humanisme dibicarakan. Manusia menjadi sadar ketika ia berpuisi, ia pun berada dalam sebuah ruang yang konkret sekaligus ruang batinnya. Ruang batin mengajak kita untuk merenungkan filsafat dan sastra (serta belajar menulis puisi) serta masyarakat seni di Indonesia. Agaknya hal itu belumlah cukup bagi Mudji Sutrisno karena ia harus merefleksikan Yunani melalui puisi dan goresan sketsanya, dan akhirnya tulisan dari kawan-kawannya tentang apa yang telah dilakukannya menjadi penutup dari bukunya.

Buku yang sangat padat dan seakan menjadi perjalanan eksistensi penulisnya memang menawarkan perjalanan kehidupannya yang beragam, dari filsuf, pecinta seni, hingga humanis. Sketsa perjalanan yang dialaminya dan terkesan terorientasi ke Yunani dituangkannya dalam bahasa puitis, metaphoris, simbolis, dan menjadi "terganggu" ketika sketsa humanisme tersebut dipenggal dengan adanya teori estetika dan seni lengkap dengan bagannya. Meskipun demikian buku Oase Estetis tetap menarik, terutama bagi masyarakat pecinta dan pengamat budaya, seni, atau siapa saja yang tertarik untuk memahami keindahan humanisme yang bersumber dari wacana dan pengalaman empiris manusianya yang diolah secara filosofis.

Irmayanti M. Budianto

Pengajar Program Studi Filsafat, Fakultas Ilmu Pengetahuan Budaya,

Universitas Indonesia

\section{Perjalanan Hidup dan Kreativitas Seni Pengrawit Unggulan}

Darsono. Pengrawit Unggulan Luar Tembok Keraton. Cet. I. (Surakarta: Yayasan Citra Etnika, 2002); xxiii + 284 halaman.

Pengrawit Unggulan Luar tembok Keraton diterbitkan oleh Citra Etnika Surakarta pada tahun 2002, diberi Kata Pengantar oleh Rahayu Supanggah, dan diedit oleh Kundharu Sabdhono. Buku ini terdiri atas lima bab: Bab I 